\title{
TALISH AND THE TALISHIS \\ (THE STATE OF RESEARCH)
}

\section{GARNIK ASATRIAN, HABIB BORJIAN}

Yerevan State University

\section{Introduction}

The land of Talish (Ṭ̂ăliš, Tāleš, Talysh, Tolysh) is located in the south-west of the Caspian Sea, and generally stretches from south-east to north for more than $150 \mathrm{~km}$., consisting of the Talish range, supplemented by a narrow coastal strip with a fertile soil and high rainfall, with dozens of narrow valleys, discharging into the Caspian or into the Enzeli lagoon. This terrain shapes the historical habitat of Talishis who have lived a nomadic life, moving along the mountainous streams. Two factors, the terrain and the language set apart Talish from its neighbours. The densely vegetated mountainous Talish contrasts the lowlands of Gilān in the east and the dry steppe lands of Mughān in Azarbāijān (Aturpātakān) in the west. The northern Talish in the current Azerbaijan Republic includes the regions of Lenkoran (Pers. Lankorān), Astara (Pers. Āstārā), Lerik, Masally, and Yardymly. Linguistically, the Talishis speak a North Western Iranian dialect, yet different from Gilaki, which belongs to the same group. Formerly, the whole territory inhabited by Talishis was part of the Iranian Empire. In 1813, Russia annexed its greater part in the north, which since has successively been ruled by the Imperial Russia, the Soviet Union, and since 1991 by the former Soviet Republic of Azerbaijan. The southern half of Talish, south of the Âstārã river, occupies the eastern part of the Persian province of Gilān.

As little is known about the Talishis in pre-modern times, it is difficult to establish the origins of the people (cf. Bazin 1980, II: 67-70). The name Tāliš, like most ethnonyms, can not be convincingly settled (see below). It appears in early Arabic sources as al-Ṭaylasān (Balādurī, al-Tabarī, Yāqūt, apud Barthold), and in Persian as Ṭālišān, and Țavāliš (Hamd-Allāh Qazvīnī, apud Dabir-siyāqi 2003: 102, 230), plural forms of Tāliš. About the Taylasān, al-Tabarī (V: 45) notes: "In the 
mountains surrounding A $\delta$ arbāijāan there used to live such peoples as the Gēls and the al-Taylasān, who did not obey the Arabs and mastered their freedom and independence". However, the ethnonym Tāliš in its original form is first found in the 16th century Armenian version of the Alexander Romance (Marquart 1903: 278), originally translated from Greek in the 5th century: Ev patmeac' nma, $t^{6} \bar{e} p^{\prime}$ axstakan $\bar{e} i$ Kaspiakan druns, merj yašxarhn T'ališ, $i$ gawain Gilanay "And he related that he is a refugee from the Caspian gates, near the country of Talish, in the province of Gilān" (Simonyan 1989: 233; for details, see Asatrian 1998: 7-8; cf. also Hübschmann 1897: 34). ${ }^{1}$

Talish has always been a land linked with either Gilān or Mughān, particularly with the centre of the latter, Ardabil, which seems to have had close ethnic and linguistic affinities with Talish until the Turkicisation of Azarbāijan. ${ }^{2}$ This is evident as late as the early Safavids, the descendents of Shaikh Șafi-al-din of Ardabil (d. 735/1334), whose mentor (morād) Shaikh Zāhed Gilāni, was probably a Talishi (cf. Ahmadi 2001: 17-18). Among the four Sufi teachers of Shāh Ismā'il, the founder of the Safavid dynasty, two had the epithet "Talishi", and other men with Talishi appellation appear among the names of the governmental officials during the Safavids and the successive dynasties. Due to the mountainous, peripheral nature of the district, however, the process of the Shi'ite proselytism in Talish, enforced by the Safavids, remained incomplete. Thus, among the Talishi-speaking communities of Iran and Azerbaijan Republic we find a sizable number of Sunnis. Save for the inhabitants of the central Talish, as well as the Turkic-speaking groups of the area, and the Gilakis, most of the Talishis in the Iranian part of Talish are Sunnis, followers of the Naqshbandiyya order. Their compatriots in the northern Talish, on the contrary, are mainly Shi'ites, except those living in some two dozen mountain villages.

Following the fall of the empire of Nader Shah in the 17th century, the Talishis established a dynasty founded by a local noble named Sayyed Abbās. In 1785 this Talish khanate became a dependency of Fath 'Ali, the khan of Kuban, after whose death (1789) Talish regained its independence.

It was only during the advance of Tsarist Russia through eastern Transcaucasia, when the Talishis made a tangible appearance in his-

${ }^{1}$ V. V. Bartol'd (1976: 273) notes that the name Tāliš has no attestations in Medieval sources.

${ }^{2}$ Note the toponymic formant -bìl/-bēl (< OIr. *waita-) in the place name Ardabill (see Bailey 1959: 116-1118), which can be traced also in Talish, cf. e.g. Lavandvìl. 
tory (see Mirzā Ahmad Lankorāni 2002; cf. also Hesām al-Salțaneh 1968). Peter the Great occupied the region for a short time in 1732; it was again occupied by Russia in 1796-1812, but finally its greater part, north of the Āstārā river, became part of the Russian domain (Weidenbaum 1888), and a century later, the Soviet Union. It was in Lenkoran, the only major urban centre within the Talishi-speaking lands, that, during the unruly period of Musavat regime in 1918-20, the Talishis enjoyed certain autonomy in the so-called Russian TalishMughan Republic. Once again, after the disintegration of the Soviet Union, northern Talish rebelled against the politically troubled Republic of Azerbaijan, and the short-lived Talish-Mughan Republic, proclaimed in Lenkoran by colonel Ali Akram Hummatov (Russian Gumbatov), was suppressed by Baku in August 1993.

After the Russian conquest, Fath 'Ali Shah Qajar divided the main territory of Persian Talish among five local clans, thus came to being the Khamse-ye Tavāleš, consisting of Kargānrud, Asālem, Tāleshdulā(b), Shānderman, and Māsāl. To complete the inventory of the Talishispeaking areas of Iran, as is known today, one may add Khoṭbesarā, Lavandvil, Âstārā, perhaps 'Anbarān (in the Namin district of Ardabil) to the north, and Māsula, with its southern and eastern fringes to the south. Today most of the Talishi-speakers inhabit the šahrestān of Talish, an administrative division of the province of Gilān.

Because of the lack of a consistent census principles both in Iran and the Republic of Azerbaijan, any suggestion on the number of the Talishis must inevitably be of speculative character. Nevertheless, due to various factors, the approximate number of the Talishi-speaking population in both parts of Talish may be estimated around two millions - one for each part. Given the reliable historical data at our disposal, this figure, at least for the northern Talish in Azerbaijan, should not be regarded as an overestimation. Indeed, already in 1894, the Russian census counted 88,449 souls in 161 rural centres inhabited by Talishis (Kavkazskij kalendar' na 1894 god). This last figure must have multiplied exponentially in the past century given the high birth rate among the people. Demographic data about the Talishis of Azerbaijan, however, have been grossly manipulated for political reasons in favour of the titular population of the republic. According to the successive censuses conducted in the Soviet Republic of Azerbaijan, the number of Talishis shows a diminishing trend: it starts 77,039 in 1926, and disappears altogether from the census in 1979. Surprisingly, however, in the 1989 Soviet census the Talishis "re-emerge" once more, numbering 21,914 (cf. Borjian 1998). 


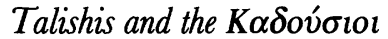

The search for real or mythical ancestors is a characteristic feature of any ethnic formation in modern times, especially in case of peoples deprived of written tradition, historiography, and other attributes of a nation state. Despite the fact that the Talishis, both in Iran and in the north, have explicit Iranian identity, the situation with the Talishis in Azerbaijan Republic, living as an enclave within the predominantly Turkic environment, has inspired the southern intellectual milieu as well. Having always been faced with the non-loyal treatment on behalf of the titular nation, the northern Talishis have acquired a keen sense of self-identity. The need for their own ancestral background among the Talishis is aggravated by the fact that South Caspian Iranian ethnic groups - the Gilakis and Mazandaranis - already have their established ancestors among the ancient population of the region; moreover, the ethno-toponymy of the Caspian area is also transparent to certain extent.

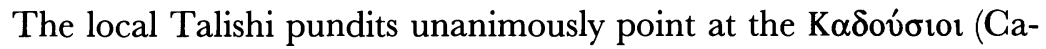
dusii) (see Schmitt), one of the ancient autochthonous tribes of the region, as the supposed ancestors of the Talishi people, in so far as the Kadusians are already becoming an element of the Talishi identity. Many items in Gilan in the Talishi-inhabited regions bear the name Kādus (e.g. a luxurious hotel in Rasht's downtown); it has even become a popular proper name for boys.

Strange as it may seem, this is one of the rare cases when a folk selfidentification with an ancient people can be, at least tentatively, substantiated with historical and linguistic backgrounds. Generally speaking, as the late Professor Igor D'yakonov (1981: 90) says, the identification of an ethnic name in the historical annals is not yet a sufficient ground for further ethnographical associations. However, with the lack of appropriate evidence on the early periods of the history of a given people or ethnic group, the identification of its name with an ancient ethnicon must be regarded as the first step in reconstructing its genetic continuity, at least nominally. Along with linguistically proven coincidence of the names, in other words the etymological aspect of the identification, for the validity of the analysis, the historico-geographical adequacy and the transparency of the ancient ethnic environment regarding its respective imprint in the modern ethnic landscape must be considered as well. In the case of the Talishis the authenticity of the identification is substantiated first of all by the relevant geographical factors, as well as by the reliability of historical 
derivations of the living Caspian peoples from the indigenous tribes inhabiting the region in ancient times. The Gilakis, the nearest neighbours of the Talishis, are unambiguously identified with the $\Gamma \hat{\eta} \lambda_{0}$ (Arm. Getk), who lived in the vicinity of the alleged ancestors of the

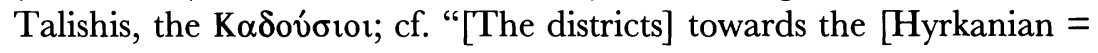

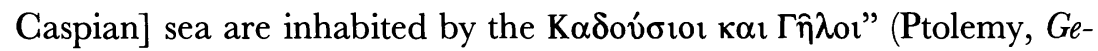
ography 6.2.5, apud Ziegler 1998: 43; cf. Hübschmann 1897: 34-35; D'yakonov 1956: 447-448). Generally, most of the ancient South Caspian ethnic designations are well localised in the system of the corresponding names of the ethnic groups inhabiting the area. Some of them can be traced only in the toponymy of the region, with reliable

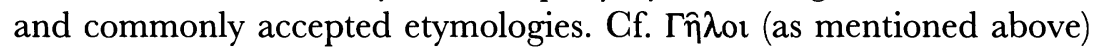

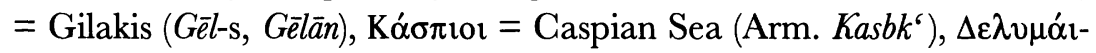

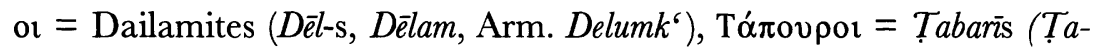

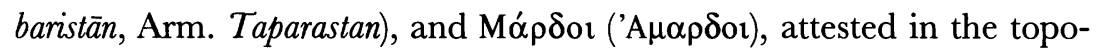

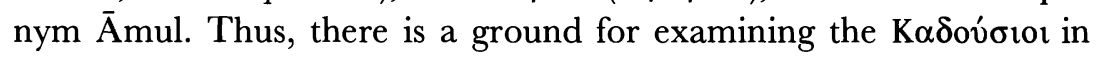
connection with the Talishis, the close neighbours of the Gilakis (= Гทेंor).

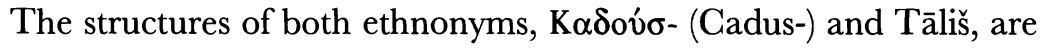
similar: they are suffixal formations with the bases kād- and tāl-. In *Kādus- the suffix must probably be read as -uš, or -iš, considering also the later Armenian version of the name, Kadiš-, in Kadšk ${ }^{6}$ (Schmidt 1999: 92); because of the lack of -š- in Greek alphabet, all Iranian forms with -š- are rendered with -s-. The intervocalic -d- in *Kād-uš (or equally in its later form, *Kād-iš) must have been developed either directly to -1- (as in case of many New Iranian forms, not necessarily from East Iranian), or through a fricative stage: $*_{-} \delta-\left(>*_{-r}-\right)$ $>-1$. The change of the initial $\mathrm{k}$ - to $\mathrm{t}-\mathrm{may}$ be explained by the palatalisation of -k- to - $\check{c}-$, under the influence of the following front vowel

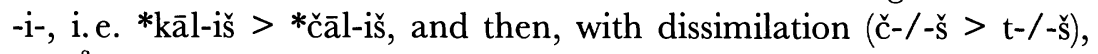
tāliš. ${ }^{3}$

Despite the obvious speculative character of the above etymology,

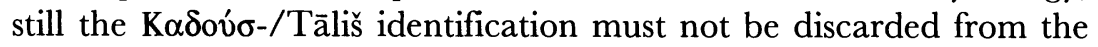
agenda of the ethnic history of the region, at least as a working hypothesis.

${ }^{3}$ Cf. Manichaean MPers. tis, Pazend Ois, Kurd. tišt "thing" vs. Pahlavi čiš, NPers. čiz < OIr. *čiš-čid-; Kurd. taštē "breakfast", NPers. čāšt, čašĩdan; on č->t- in initial position; cf. also Manich.

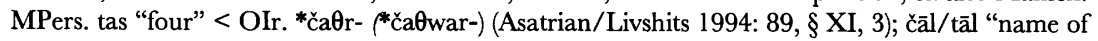
a demon", etc. (generally, on č-/š- > t-/š- dissimilation in Iranian, see Reichelt 1927: 37). 
Studies on Geography, History, and Ethnography

The writings of European Travellers from earlier periods, often in connection with Gilān, include, but are not limited to, James B. Fraser (1826), Eduard Eichwald (1834), Aleksander Borejko Chodzko (1842, 1852), Il'ya Nikolaevich Berezin (1952), P. F. Riss (1855), Boris Andreevich Dorn (1866), Gustav Radde (1885, 1886), Jacque de Morgan (1894-1904), H. L. Rabino (1917), Boris V. Miller (1926), and G. F. Chursin (1926). The travel notes, allegedly collected for Dorn in 185961 by a certain Mirzā Ebrāhim (1976), contain economic geography with valuable data on Talish (: 191-219).
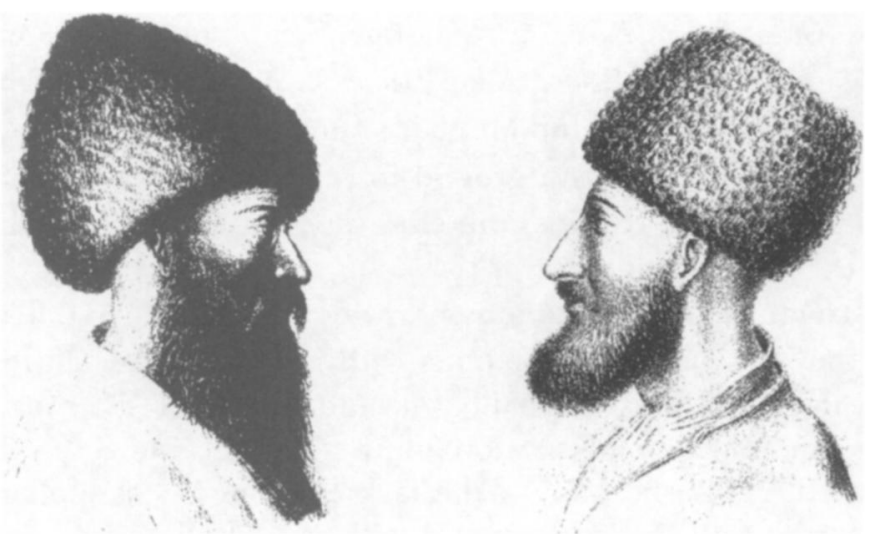

Fig. 1. A Highlander Talish (left) and a Lowlander Talish (right)

(Radde 1886: 414-15)

Macel Bazin's Le Tâlech (see below) is an excellent source on the geography of the Persian Talish. ${ }^{4}$ On the geography of the northern Talish a valuable source is the Atlas Azerbaidjanskoj SSR (Baku-Moscow, 1963). So is Jaque de Morgan's Mission scientifique en Perse (1894-1904), which contains a geography of the Russian Talish and the Mughān steppe (I: 231-288), archaeology of Lankorān region (IV:13-125), and a short account of the geography of the Persian Talish (I: 229-230). A survey of historical monuments within Persian Talish is conducted by Sotudeh 1970. Certain historical sources covering Talish are touched upon in Encyclopaedia Iranica, s. v. "Gilān", while Encyclopaedia of Islam

${ }^{4}$ For individual villages on the Persian side, one may consult Farhang-e äbädihā-ye kešvar (Village Gazeteer). Other references are Encyclopaedia Iranica and the Persian encyclopaedias being published in Tehran. 
offers a very short article under "Talish". ${ }^{5}$ The voluminous Ketäb-e Gilān (1995) covers Talish as part of the province Gilān, but with little originality. Garnik Asatrian's essay (1998: 3-13) on Talishis offers a general but updated information on geographical distribution, ethnography, language and the identity of the Talishis (see also Vil'čevskij 1957).

History of Talish is yet to be written as little has been published on the subject. Of particular importance are the documents published in separate volumes or within more general historical accounts, e.g. Mirzā Ahmmad Lankorāni's (2002) Axbār-nāmeh, written in 1883 on the khanate of Lankorān during Russo-Persian wars. The "Four treatises" ("Abdoli, ed., 1999a; reviewed by Borjian 2002) contains two important historical essays: Javāhermāme-ye Lankorān, a local history and geography written in 1869 by Sa'id 'Ali Barādgāhi, a Talishi nobleman who carried modern ideas common among the intellectuals of the Russian Transcaucasia; and Travel journal in Talish, ${ }^{6}$ a 1890 report to the Shah by Hesām al-Salțaneh (see 1968), the governor of Gilān, concerning disputes among the feudal lords of Talish.

Only recently the Talish history has gained attention in Iran. Published materials include Āqājāni's essays (1999) on the history of Talish; Ahmadi's (2001) survey on the modern history of Talish since the Safavids; and Abdoli's work (1998) on the Constitutional Revolution. Other works by 'Abdoli $(1990,1999 b)$ offer certain data on history, though they are not necessarily dependable, particularly his manipulation of earlier periods (e. g. 1989c).

One may also find ethnographic data on the Talish in earlier Russian publications, such as Sbormik 1894, and Spisok 1927. Later Soviet studies are few and relatively poor in this regard, as Soviet reference books generally tend to follow the standards set by the authorities in Baku, who systematically denied the mere existence of Talishis as a distinct people. Contrary to one's expectation, there is hardly any sizable information in the publications of the Soviet Republic of Azerbaijan, if we judge based on Talish-related materials published in Azärbayjan sovet ensiklopediyast (IX, Baku, 1986: 134-136). An exception could be Izmajlova's (1977) study on the architecture of the Talish dwellings. On the other hand, it appears that the cultural ambitions of the Talishi intellectuals have somewhat augmented in the post-Soviet years. Talishi publications have rather increased in Baku, but as one may

\footnotetext{
By W. Barthold in the first ed., IV: 641; and by Bosworth in the second ed., X: 166 .

${ }^{6}$ Formerly published by Ebrāhim Safâ'i.
} 
expect mostly in Azeri Turkish. Recently, the periodical Talyšskij Vestnik is published in Moscow, and Talishi items appear on the Internet, e.g. in the websites www.talishca.org and wrew.css.mps.ru/astara (see in detail Ter-Abrahamian 2005). Moreover, Talish has received some attention in references covering Soviet or Eurasian peoples, e.g. Aglarov 1994.

The secluded way of life makes Talishis one of the most interesting peoples across Iran. Particularly, short-distance annual migration and the sheer difference between the summer encampments in the altitudes and the winter occupation of rice fields. Marcel Bazin's contributions to the ethnography of the Persian Talish are the most comprehensive works ever devoted to the ethnic groups in Iran. His Le Tâlech (1980) contains information on: (i) the environment: climate, geology, hydrology, flora and fauna; (ii) human geography: demography, agriculture, nomadic life; and (iii) the Talish and their Gilaki and Turkic-speaking neighbours: migrations, economic and cultural interactions. Moreover, there are Bazin's individual articles on Talish: Turkic penetration (1975), the markets (1977), culture (1978), and overviews (1974, 1996). Bazin's studies of Talish may also be found in his thematic and regional studies on the ethnography of Iran and the region, e.g. his articles on the ethno-socio-professional groups of the Caspian littoral coast (1982) and on the regional identity (2000: 351352). The northern part of Talish is only briefly covered in Bazin 1980 (: 209-214).

A major contribution to the ethnography of Talish is the article by Garnik Asatrian (2002). He describes in detail the folk beliefs concerning animal husbandry, particularly focusing on the popular patron deity of the neat cattle, the so-called Siyāh Gāleš, the Black Shepherd. It is interesting to note that this mythological character is traced exclusively among the Talishis of Gilān (along with the Gilakis and, to certain extent, the Mazandaranis), while the same character is featured in the north under the universal name of the Prophet Khizir. In Māzandarān and Gilān, including Talish, the shepherds breeding neat cattle and living by making dairy products are called gāleš, while the shepherds breeding small cattle are known as kord (kurd). Asatrian derives the term gāleš from OIr. *gawa-raxšaka-, lit. "the protector of cows".

On ethnography, one may also find numerous articles in Persian periodicals. The pre-revolutionary journal Honar o mardom contains several articles pertinent to Talish. Viže-ye Täleš (a supplement to weekly Kädeh (sic!)), of which five issues were published until the summer of 1995; it offers articles on the ethnography, language, folk lit- 
erature, etc. The periodical Āvā-ye šomāl published a special issue Vižeye täleših $\bar{a}$ (6 fascicles came out during 1997-2000). From 2000 began Tāleś-senāsi, of which at least five issues are out. There are also periodicals publishing pseudo-scholarly materials, such as Faslnäma-ye tahqiqäte Täleš (1/1, 2001 to $2 / 1$ (5th-6th issues), 2003), a quarterly dedicated entirely to Talishi studies, which fieldwork information can be hardly distinguished form the genuine materials borrowed, usually without citation, from the works by Marcel Bazin, etc. There are also articles, mostly translations from Turkish published in Baku, on northern Talish. Articles on Talish can be found also in periodicals published in Gilān, such as Gilevā, Gilān-e māa, Farhang-e Gilān, and Naqǔse qalam, as well as in the multi-volume encyclopaedia Gilān-nāmeh, arranged by subject.

There are several non-academic publications on the ethnography of Talish as well. 'Ali 'Abdoli, a local authority, is prolific on his homeland. His first collection of articles (1984) is devoted exclusively to Talish; it deals with the economy, markets, music and songs, and also includes short stories on common beliefs. His second collection (1990) is partly (: 15-125) dedicated to Talish; it has materials on the towns, festivals, ceremonies and superstitions, which show the underlying substrate of pagan beliefs among the Talishis. 'Abdoli 1992 is on the nomadic life of the Talishi mountaineers.

\section{The Language}

A subgroup of North-Western Iranian languages, Talishi is closely related to the Tâti group of dialects spoken across the Talish range in the south-west (Kajal and Shāhrud) and south (Tārom), constituting together the larger "Tatic" family. ${ }^{7}$ Although we have no attested monuments of Talishi, the language termed in Iranian dialectology as "Āzari" can be considered as its forebear. Miller's (1953: 227ff.) hypothesis that the Āzari of Ardabil, as appears in the quatrains of Shaikh Șafi, was a form of Talishi, was confirmed by Henning (1954). An inclusive discussion on the subject is provided by Yarshater ("The Iranian Language of Azabaijan"), and Hasmik Kirakosyan (2004a, 2004b). ${ }^{8}$

\footnotetext{
${ }^{7}$ For a language map, see Bazin 1980, II: 84, fig. 101. For the place of Talishi within the Tatic socio-linguistic group, see Stilo 1981. For a comparison with Southern Tâti, see Morgenstierne 1958. See also G. L. Windfuhr in CLI: 294; idem, s.v. "Dialectology", EIr.

${ }^{8}$ See also Hājatpur 1990b (based on Yarshater) on the affinity of the three poems appearing in Badr Sharvāni's Divān.
} 
In spite of dialectal varieties, salient characteristics of Talishi may be summarised as follows. It differs from Persian by an enlarged vowel system, by addition of $\partial$, a central vowel, and, at least in its northern and central subdialects, also by $\ddot{u}$, a front vowel. ${ }^{9}$ As in the case of most Iranian dialects, Talishi possesses two cases: the direct or the subject case, and the oblique or the genitive and object case. In Asālemi, a central Talishi dialect, the case endings typically are: sing. dir. $-0, \mathrm{pl}$. dir. $-e$, sing. obl. $-i$, pl. obl. $-u n .^{10}$ The verbal system diverges from most other Western Iranian dialects by the application of the present stem for the imperfect and the past stem for the present, e.g. Asālemi vrij-/ vrit- 'run' a-vrij-im 'I was running' ( $a$ - is the durative marker), b-a-vrit-im 'I run, I am running'. Further, verbal affixes, including the negative $n V$, cause a reshuffling of the elements of conjugation in the present tense, e. g. ni-m-a-vrit 'I don't run, I am not running' where the personal "ending" precedes the marker and the stem. Syntactically, Talishi, like Tāti, employs the ergative construction in past transitive verbs based on the past stem; accordingly, the agent of the verb appears in the oblique case, the logical direct object in the direct case and the verb agrees with the direct object, e.g. Asālemi esbun (obl. pl.) gud harda (sg.) 'the dogs ate flesh' (Yarshater, "Talish": 166).

Turkish and Gilaki Influences. Talishi has long been under the strong influence of the neighbouring languages. In the south, the infiltration of Gilaki is more noticeable; especially on the plains of Fumanāt, where the presence of the Talishis is more recent, a highly mixed Talishi coexists side by side with Gilaki ('Abdoli 2001: 31-33). Turkish, on the other hand, has rapidly been spreading in the northern parts of the Persian Talish due to the recent migrations from the west. In the urban centres of Āstārā and Hashtpar, located on the commercial highway stretching from Enzeli to Āstārā, Turkish has already replaced Talishi. ${ }^{11}$ South of Asālem, however, Turkish gradually loses edge (Bazin 1975); thus, central Talishi is considered the purest of all Talishi dialects.

Talishi and Armenian. There is no attestation of the Talishi-Armenian direct contacts. However, the Talishi vocabulary contains a number of important lexemes of unambiguous Armenian origin, penetrated into

\footnotetext{
${ }^{9}$ Sokolova (1953: 105, 109ff.) demonstrates the interchangeability of $u$ and $\ddot{u}$ in certain positions and among dialects (see also Miller 1953: $33 \mathrm{ff}$.; Schulze 2000: 9; Rafi'i-'Ali 2001).

${ }^{10}$ Yarshater 1996. Cf. Māsāli: sg. dir. - Ø, pl. dir. -en, sg. obl. -i, pl. obl. -un (Nawata 1982: 97); Māsulei: sg. dir. - Ø, pl. dir. -en, sg. obl. -e, pl. obl. -on (Lazard 1978: 255).

${ }^{11}$ For Talishi-Turkish convergence, see Windfuhr 1987.
} 
the language probably through Caucasian Turkish or Kurdish. Cf. kutān "plough" (Arm. dial. k'ut'an, Classical Arm. gut'an), lord "coagulated blood" (Arm. lərd, lerd), ləs "panther" (Arm. lus(an) id.), pārzən "strainer, filter" (Arm. dial. parzon, Kurd. pārzōn), pənd "strong, firm" (Arm. dial. pənd-, pind), puš "hay; sweepings" (Arm. dial. p'uš "thorn"), xāšīl "porridge" (Arm. dial. xašil), hand "furrow" (Arm. dial. hand, Udi hännd, Classical Armenian and "cultivated land"), šīv, žīv "branch, twig" (Arm. dial. šiv), vəš "hemp" (Arm. vuš), galgal "sort of

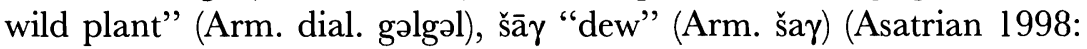
10), bärsim "threshold" (from bar "door" < OIr. *dwar-, and Arm. dial. sim, sem, šem < Class. Arm. seam "threshold"), hävälik "sort of edible herb" (Arm. dial. haveluk, aveluk; cf. Azerb. Turkish evelik, Jewish Tati ävälug, etc.), mambür, ambür "moss" (Arm. mamur), sün(d) "pillar" (Arm. dial sun, Class. Arm. siwn) (from V. Voskanian's field materials), etc.

Dialects. The north/south division of Talishi dialects, motivated by administrative boundaries, does not reflect the linguistic realities. In reality, the chain of Talishi dialects is divided into three main types: southern, central, and northern. Southern Talishi, spoken in the districts of Māsule and Māsāl, is actually closer in type to mutually more intelligible with the neighbouring Tâti idioms (Yashater 1959) than the central and northern Talishi. On the other hand, the dialects spoken in the Āstarā area in the northern limits of Persian Talish show close affinity with those, which are further in the north, in Lankorān, Lerik, Masally, and Yardymly. According to the brief survey conducted by Bazin (1980, II: 68f., 189ff., figs. 94f.), based on 48 glosses such as 'mountain', 'aunt' and 'son-in-law', the major isoglottic barrier is between the central dialects of Asālem-Tulārud and the northern dialects of Kargānrud-Khotbesarā (weighting 16 points out of 48), a split much sharper than the one between Māsāl and Tāleshdulāb ( 6 points), as well as the two members of the southern group, namely Māsula and Māsāl (2 points). ${ }^{12}$ The table below represents the comparison of these dialects. $^{13}$

${ }^{12}$ On the dialect variation with respect to human geography, see also Bazin 1979, idem

${ }^{13}$ Based on: Lazard 1978, 1979a, 1979b; Nawata 1982; 'Abdoli 1984, 1991; Hājatpur 1997; Yashater 1996; Morgan 1904; Miller 1930. 


\begin{tabular}{|c|c|c|c|c|c|c|c|c|}
\hline Gocalities & 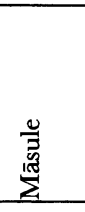 & 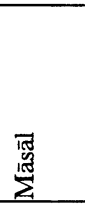 & 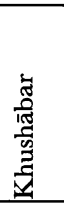 & 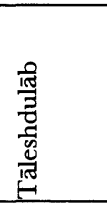 & 焉 & 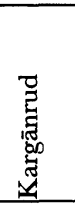 & 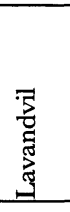 & 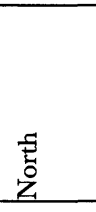 \\
\hline sister & $x \hat{a}$ & $x \hat{a}$ & & xâlâ, xolo & & ho & hura? & hov(a) \\
\hline $\begin{array}{l}\text { woman, } \\
\text { wife }\end{array}$ & yen & žen & žen & $z \bar{z} \bar{e}$ & žen & žèn & $\check{z} \partial n$ & žen \\
\hline wife's sister & yeg $x \hat{a}$ & ženxâ & & žen-xâliâ & & $\begin{array}{l}\text { *žèn- } \\
\text { ho }\end{array}$ & & $\begin{array}{l}\text { *žen- } \\
\text { hov(a) }\end{array}$ \\
\hline boy, son & $z o a$ & $z u^{\prime} a$ & & zue & $z u^{w} a$ & $z u a$ & & $z o a$ \\
\hline $\begin{array}{l}\text { daughter, } \\
\text { girl }\end{array}$ & $\operatorname{kel}(l) a$ & kina & & kilu, kela & & kela & & kina \\
\hline bride & veyb & geša & & vayu & vayu & & & vayü \\
\hline I & $a z$ & $a z$ & & $a z$ & $a z$ & as & & $\hat{a} z$ \\
\hline my, mine & čman & $\begin{array}{l}\text { čaman, } \\
\text { ceman }\end{array}$ & & čemen & čməm & cömön & & čm \\
\hline we & $a m a$ & ama & & $a m a$ & $a m a$ & ama & & ama \\
\hline white & $i s b i$ & $i s b i$ & $i s b i$ & $i s b i, i s p i$ & $\begin{array}{l}i s b i \\
i s p i\end{array}$ & $i s p i$ & & sipi, sipi \\
\hline face & dem & $d i m$ & & $\operatorname{dim}$ & & & dim & dim \\
\hline mouth & $\begin{array}{l}\text { da:n, } \\
\text { qar }\end{array}$ & dahan & & $g a(f)$ & $\begin{array}{l}\text { gav, } \\
\text { gaf }\end{array}$ & ghav & $g a v$ & gav \\
\hline eyebrow & & abrom & & bera & & & & bav \\
\hline tear & & asrrk/g & & aserg & & & ase & $\begin{array}{l}\text { ase, } \\
\hat{a}(r) s\end{array}$ \\
\hline weeping & $\begin{array}{l}b ə- \\
\text { raman }\end{array}$ & $\begin{array}{l}\text { bar- } \\
\text { mamse? }\end{array}$ & $\begin{array}{l}\text { be- } \\
\text { rame }\end{array}$ & $\begin{array}{l}\text { berame } \bar{e} \\
\text { berameste }\end{array}$ & $\begin{array}{l}\text { bera- } \\
\text { maste }\end{array}$ & $\begin{array}{l}\text { ba.a- } \\
\text { mie }\end{array}$ & & bame \\
\hline thirsty & tišir & rešir & & tēšy & & & & $\begin{array}{l}\text { taši, } \\
\text { tašyan }\end{array}$ \\
\hline hen & karg & karg & & karg & karg & kàk & & $k a q$ \\
\hline chicken & & gija & & $k i j a$ & & & & $k i z ̌ a$ \\
\hline bear & $x \partial r s$ & xers & & & & xörs & hers & hirs \\
\hline
\end{tabular}




\begin{tabular}{|c|c|c|c|c|c|c|c|c|}
\hline cat & puču & $\begin{array}{l}\text { puču, } \\
\text { pišr }\end{array}$ & pušu & pušu & & pišik & piš & kete \\
\hline $\operatorname{dog}$ & әspa & $a s b a$ & & $e s b a$ & $\begin{array}{l}\text { esba, } \\
\text { espa }\end{array}$ & $\ddot{o s} b a$ & & stpa \\
\hline louse & espej & $e s b \not j$ & & $i s b i j$ & & & & sebizz \\
\hline iron & âsen & asün & & & & ôsun & & $\begin{array}{l}\text { osm, } \\
\text { ossön }\end{array}$ \\
\hline water & $\hat{a} v$ & $\hat{a} v$ & $\hat{a} v$ & $\hat{a} v$ & $\hat{a} v$ & $o v$ & $u v$ & $o v$ \\
\hline milk & šat & $\check{s} a t$ & & šet & šet & šöt & & šnt \\
\hline cloud & $x \partial r$ & $x a r$, sara & & xer & & $m e h$ & & her, âva \\
\hline willow & & $v i$ & & $v i$ & & & & $v i$ \\
\hline barley & $y a$ & $j a$ & $\check{z} a$ & $\check{z} a$ & & & yav & yava? \\
\hline apple & sef & sif & & sif & sif & sef & $s \bar{e} f$ & sef \\
\hline yesterday & zer & $\operatorname{zir}(i)$ & & zir & $i z a r$ & zina & & zina \\
\hline day & roz & ruz & & & $n i j$ & $n i j$ & & rüž \\
\hline below & & jir & & $\dot{y} r$ & $\ddot{j} r$ & & & $\check{z} i$ \\
\hline $\begin{array}{l}\text { to say, past } \\
\text { stem }\end{array}$ & vât- & vât- & & vât- & vât- & & & vot- \\
\hline to eat & hard- & hard- & & & hard- & & & hard- \\
\hline to see & venn- & vind- & & vind- & vind- & vînd- & & vind- \\
\hline
\end{tabular}

Written Sources. As mentioned above, the corpus of "Āzari" materials extant from former centuries can hardly be labelled as distinctly Talishi; they should rather be regarded as a common ancestor of the Tāti-Āzari-Talishi group of dialects (Kirakosyan 2003). In the last two centuries, however, specifically Talishi oral accounts have been collected by foreign travellers and scholars (see below). The natives too have published materials worthy of attention.

Besides Shaikh Safi's quatrains, there are two mediaeval collections of poems belonging to the Fahlaviyyāt genre, which are generally considered Gilaki, but sometimes also Talishi (e. g. Tafazzoli, s. v. "Fah- 
laviyāt", in EIr.): (1) A collection of quatrains attributed to Sayyed Sharaf-al-Din known as Sharafshāh of Dulā' or Dulāb (i. e., Tāleshdulā[b]), who probably lived in the 13th century (Sharafshāh 1979: introd.; idem 1982: 7-33; for studies, see Madani 1984; 1990: 376); (2) The poems of Qāsem Anvār (d. 837/1433-34) (1958: 342-44, 347; on the poet, see Browne 1928, III: 473-87; for studies, see Tadayyon 1945; Dowlatābādi 1984).

Talishi enjoyed a standard written form only in a short period of early Soviet rule, when, among many other idioms of the Caucasus, it gained official recognition and was taught to school-children. The standard Roman script, devised in the late 1920s, was ruled out a decade later. The educational and political publications from those years, ${ }^{14}$ particularly the periodical Səya Toləš 'Red Talish', remain an important source for the study of the language, although the Talishi of those years is crammed with neologisms and Russian borrowings. In the post-Soviet era sporadic publications have appeared in Talishi. The periodical Toleši sado 'Voice of Talish', which began in 1991 and discontinued after its eighteenth issue, features articles in a Cyrillicbased Talishi, as well as in Turkish. ${ }^{15}$ There are also individual volumes such as Yolon syxan/Talyšskie poslovicy ('Talishi proverbs', Baku, 1990), and Novruz Mamedov's Toleši armağon (1993).

The Talishi speakers of Iran too developed interest in publishing their folk literature, especially since the early 1970 s. ${ }^{16}$ An early example is a versified account (manzumeh) by Farāmarz Masrur in 1973, supplemented by a glossary of 230 items. Here again, the contribution of 'Ali 'Abdoli is major. His Tarānehā-ye šmāl includes, among other Caspian dialects, Talishi songs from Shānderman, Rezvānshahr, Punel, Parasar, Dināchāl, and Lavandvil ('Abdoli 1989a: 35-152), accompanied by a glossary (: 259-282). The songs he collected from paddy fields (idem 1989b) appear in Roman transcription. The Talishi section of 'Abdoli's anthology (2001a) includes poems from the past (Āzari?: 39-53), contemporary Lankorāni (:54-86), as well as 'Anbarāni, Asālemi, Māsāli, Tāleshdulā'i, Khushābari, and Fumani (: 87-141), all rendred in Perso-Arabic script, accompanied with the Persian translation. 'Abdoli's own verses appear in Aftāvajār (1991), a collection of 33 Talishi and Tāti poems. Additionally, specimens of Talishi appear in other volumes published by 'Abdoli (esp. 1984, 1990,

${ }^{14}$ Miller (1953: 12) lists sixteen books and booklets published during 1931-35.

15 'Abdoli 2001: 34f., 49. The periodical seems to have recently begun republishing (Faslnäme-ye tahqiqāt-e Täleš 1/1, 2001: 149).

${ }^{16}$ A number of local poets are introduced in 'Abdoli 1999. 
1999b). Another recent publication is Nāser Hāmedi's Čan-ba-rā (1999), with seventeen Talishi poems in the dialect of Māsāl supplemented by Persian translation. Moreover, Talishi verses appear sporadically in various periodicals of Gilān, and surely in Viže-ye Täleš and Faslnāma-ye tahqiqāt-e Tāleš (see above).

It should be noted that on the Persian side, Talishi has never had a standard orthography. The Roman transcription is occasionally used without keeping to any logical uniformity of rules (see, e. g. Viže-ye $T \bar{a}-$ leš, no. 3).

Basic Overviews. Major bibliographical outlines have appeared in successive reference works on Iranian dialectology: Wilhelm Geiger in Grundriss (1898-1901), H. W. Bailey (1936), Georg Morgenstierne in Iranistik (1958: 173 f.), Iosif M. Oranskij (1960, 1963), Georges Redard in Current Trends in Linguistics (1970), Pierre Lecoq in CLI (1989: 299 ff.), and L. Pirejko in the Osnovy (1991). Recent bibliographies in Madani (1990), 'Abedi 1993, and 'Abdoli (2001a: 37-49), though incomplete and inaccurate, are the only available Persian compilations.

Earlier Studies. One of the earliest travellers and scholars who tried to identify ethnic groups by collecting data on their life and language is Eduard Eichwald (1834: 436f.), who included in his travel notes a list of 35 Talishi and Gilaki words.

A notable collector of the folk traditions of northern Iran was the Polish scholar Aleksander Borejko Chodzko, who published important Talishi materials: specimens of popular songs in Talishi, in Roman transcription, with extensive notes on the vocabulary (1842: 556-567) and translation (: 506-510). In Chodzko 1852 we find Talishi songs along with those collected from Gilān and Mazandaran. Materials gathered by Chodzko were used by the Russian Orientalist Il'ya Nikolaevich Berezin, who introduced a grammar (1853, I: 24-57), a glossary (I: 24-55), songs (II: 38-46, taken from Chodzko), and a PersianTalishi-Gilaki-Mazandarani vocabulary of about 200 glosses (III: 2-7). In spite of the inaccuracies and limitations, the contributions by Chodzko and Berezin are considered pioneering efforts in Iranian dialect studies. A contemporary of the latter scholars was P. F. Riss (1855), who wrote a thirty-page Talishi grammar, followed by some 250 words, 70 verbs, and 40 short sentences and a few songs.

In his travel report on the Caucasus and southern Caspian shores, Dorn (1862: 363) mentions that he requested Ebrāhim Beyk of Lankorān to compile a Talishi-Russian glossary and a grammatical sketch 
of the dialect. The results have never been published but are reportedly kept at the Shchedrin library (Madani 1990: 363, 373). In his Caspia (1875), Dorn pays extra attention to Talishi, along with Tati, Mazandarani, and Gilaki (: 217-220).

The fifth volume of Jaques de Morgan's Mission scientifique en Perse (1904) contains valuable Talishi materials: a list of 769 words from the subdialects of Kargānrud and Lankorān (: 261-279), a short grammar (: 280f.), and the text "Contes en Lenkorāni" (: 282-287), dated 16 Zu'l-qa'da 1307/1890, compiled by a local scribe upon Morgan's request. Morgan's linguistic study received a negative review by Oscar Mann (1926: xxiii).

In spite of limitations and inaccuracies, the nineteenth-century studies bore great achievements in Iranistics in general and Talishi studies in particular. This statement is confirmed when we compare the first mention of Talishi in the Russian relevant literature as "one of the six types of Persian"17, with the state of knowledge on the idiom in the turn of the century as appears in the Grundriss, where Wilhelm Geiger (1898-1901) offers his groundbreaking comparative study of the Caspian Sprachbund (Tati, Talishi, Gilaki, Mazandarani, and Semnāni ${ }^{18}$ ) collectively illustrating their diachronic affinity (I/2: 344380). The following introductory remarks by W. Geiger about the classification of the dialects include an outline of the phonology, nominal system, pronouns, and verbs, together with a more or less short account of word-formation. In addition to the published works, in his bibliography Geiger cites (: 345) two unpublished works: Talishi texts and a glossary kept as manuscript Or. no. 932 at St. Petersburg University, from which Paul Horn had extracted Talishi data for himself; and a Talishi grammar and glossary (as noted in Journal of Royal Asiatic Society Fournal 20, 1862-63: 64). W. Geiger was also able to refer in part to unpublished material collected and examined by Bernhard Dorn and Carl Salemann of the Imperial Academy of Sciences in St. Petersburg.

The following early collections are probably never published. Rabino claims to have collected a large corpus of folk tales and songs

${ }^{17}$ Starčevskij’s Spravočnij entsiklopedičeskï slovar', St. Petersburg, 1848, s.v.“Talyš".

${ }^{18}$ Based on more recent scholarship, Semnāni should not be linked so closely with this group. According to Asatrian (Manuscript), Taleshi shares a series of important lexical, phonetic, and grammatical isoglosses with the dialects of the Near Caspian and Aturpatakan regions, irrespective of their North-West or South-West dialectal affiliation (Āzari, the language of the socalled Fahlaviyyät, Zaza, Gorani, Tati, etc.). He defines this continuum of dialects as Near Caspian-Aturpatakan Sprachbund of the Iranian dialects (Asatrian, Manuscript, idem 1995: 410). 
in Gilaki and Talishi during the first decade of the 20th century (Rabino 1943-44: 52). We know from the proceedings of the International Congress of Linguists in 1938 ('Abdoli 2001: 39), that the Swiss Orientalist E. Baer collected in his 1932-33 trip to Iran some 12,000 words from various dialects, some from Gilān, including the Talishi of Asālem.

Studies on Northern Talishi. Soviet scholars followed their Russian predecessors in collecting and studying Talishi dialects within the borders of Soviet Union. An early Soviet study is that of Nicolas Marr (1922), which is now considered outdated, as it is written in keeping with his "theory of language".

A comprehensive study of Talishi is provided in Miller's two major works. His Talishi texts (1930), collected in his trips of 1902 and 1925 to Lankorān, includes a body of short tales, popular songs, long stories, idioms, folk medicine, cooking recipes, and poems, supplemented by a Talishi-Russian-French glossary of over 2000 words, ${ }^{19}$ which does not exclude numerous Turkish and literary Persian loans. Miller's Talishi language (1953) is a fundamental source for the study of northern dialects of Talishi. In addition to an intensive treatment of the grammar, it has a section on the historical-comparative study of the language, substantiating the close affinity of Talishi and Āzari, including the transcription of the twenty quatrains (dobeytis) of Shaikh Safi of Ardabil. The book is supplemented by three passages from the Seina sor 'third-grade' school text (1931), Talishi translation of the Communist Manifest, and certain speeches of Joseph Stalin (: 241-253). ${ }^{20}$

Sokolova (1953: 104-117) challenged Miller on the phonology of various Talishi dialects. In her book she provides texts from Lankorān and Zuvand, proposing her own system of phonemes (: 117-121).

The Pirejko's Talishi-Russian and Russian-Talishi dictionary (1979) is based on the texts published by Miller and other Soviet scholars, as well as the vocabulary in the periodical Saya Toləš. Having 6,600 words, it is the most inclusive glossary on northern Talishi. The dictionary is supplemented by a grammatical sketch (: 321-352), an updated version of which appears in the Osnovy ${ }^{21}$ (Pirejko 1991). Again

${ }^{19}$ Some 2370 entries from this glossary are reproduced on the Internet site www.talishica.org, which also has the digitised versions of two other glossaries: a Talishi-Russian-English-Azeri Turkish (ca. 600 entries), and a Russian-Talishi.

${ }^{20}$ Miller has at least one article on Talishi: "On the Suffix $-i$ in the Talishi Substantives" (1948; cited in Oranskij 1975), which should have been incorporated in his 1953 monograph.

${ }^{21}$ A pure compilation including mostly outdated materials, as most of the volumes appeared in this Series (see Asatrian 2001). 
by Pirejko there are a university dissertation (1956), a comparative study of the ergative construction in Kurdish and Talishi (1961), and a summary of Talishi in the Languages of the Peoples of the USSR (Pirejko 1966: 302-322).

Major studies by the natives of the Soviet Talish include Mamedov's (1971) dissertation on the dialect of Shuvi, and Rajabov's (1992) Talishi-Turkish dictionary of about 5,000 entries. Several more studies have been published in recent years ('Abdoli 2001: 47 ).

A recent study of the language by Schulze 2000, based chiefly on an oral account from the village Shuvi, employs modern linguistic theories, as well as statistical methods, concentrating on the features of actance typology to explain the architecture of the "operating system" of the language and the emergence of split structures from both typological and cognitive perspectives. The diachronic handling of the idiom, however, is not without major flaws (Borjian 2004; see also Guizzo 2002).

Studies on the Talishi of Iran. It was only after the completion of studies on the Talishi of the northern territories that scholarly publications on the Persian side began - a process that is still underway. We may recall that, compared with the north, in which a standard form of the language was established in the 1930s, in Iran the dialectal variation is much more pronounced, with the presence of all the three groups of dialects, i.e. southern, central, and northern. Nevertheless, no serious study aiming at an identification of the subdialects is conducted, save for brief isoglottic surveys of Bazin (1979, 1980, 1981), as noted above.

Only two dialects are studied in some detail. Gilbert Lazard's study is based on the data collected in 1949 from Māsule and consists of a grammar (1978), texts with French translation (1979a), and a glossary of 430 words (1979b). Subsequently, there is a detailed grammar of Asālemi by Ehsan Yarshater (1996), of which the texts and glossary remain to be published. So are the linguistic materials collected before the Islamic Revolution of 1979, from other districts of Talish by the same author, who has studied also two Tāti dialects closest to Talishi: those of Shāhrud of Khalkhāl (1959) and Kajal (1960), as well as the Southern Tāti group (1969). To these one may add Tetsuo Nawata's brief study (1982) of the dialect of the village Lung in Māsāl. Worth mentioning is also Windfuhr's (1987) study of the convergence of Talishi with Turkish.

Since our intention is to introduce all publications on Talishi, nonscholarly works are included as well. 'Ali 'Abdoli's Farhang (1984b) in- 
vestigates the Talishi of Tāleshdulā(b), a sub-dialect of its administrative centre, Rezvānshahr (formerly Rezvāndeh), in the first edition (1984; reviewed by Sādeqi 1984), and that of the village of Ardajān in the second (2001b; reviewed by Rezāyati 2002). The Talishi entries are compared with the Tati of Kolur, the administrative centre of Shāhrud in the Khalkhāl šahrestān of Ardabil province. The Farhang, however, includes more than what its name claims. The section on grammar (: 65-119), taking into account the dialects of Tāleshdulāb, Kolur, Khushābar, and Lavandvil (the northernmost subdialect of the Iranian Talish), is unfortunately unmethodical and hence of limited merit. The book is further extended by a short glossary of Āzari from available texts (: 281-305), a Lankorāni-Tāleshdulā'i-Persian glossary (: 309-353), an index of the Tâti words appearing in the body of the dictionary (: 357-395), and finally a list of Talishi and Tāti idioms (: 399467). In spite of amateurishness, the book may serve to identify certain subdialects, on account of insufficient scholarly studies on Talishi dialects of Iran.

Some other natives of Talish contributed to the field by writing university theses on the dialects of Khushābar (Hājatpur 1990a; also 1997, 2003), Tāskuh of Māsāl (Naghzgu 1995; also 1996), Māsule (Mohammadizadeh 1996), and Parasar (Rezāyati); and on Talishi phonology (Sheykh Sang 2001) and Talishi clothing (Khādemi 1997). ${ }^{22}$ Many of these studies suffer methodical problems, and the most detailed parts of their treatment are limited to the features the dialects share with standard Persian, being thus of limited value. One should not forget that Talishi, as most other living Iranian languages and dialects, is heavily influenced by Persian throughout the history, and, therefore, the dialectologists should give priority to the authentic traits rather than indiscriminately treat every grammatical part, as if the language of an entirely autonomous culture were being studied.

The studies on the Talishi dialects of Iran can be summarised as follows: 'Anbarān (Amiriān 2001), Asālem (Yarshater 1996; Rezāyati 2003 (Nāvrud)), Tāleshdulā(b) ('Abdoli 1984, 2001b; Hājatpur 1997; Rezāyati (Parasar); idem 2003 (Šafārud of Punel); Guizzo (Rezvānšahr)), Khushābar (Hājatpur 1990a, 2004), Māsāl (Nawata 1982; Naghzgu 1995, 1996 (Tāskuh)); Māsule (Lazard 1978-79; Mohammadizadeh 1996). ${ }^{23}$

${ }^{22}$ See also Āzmude 1994; 1996a,b; 1998 (terminology of rural economy, birds, etc.); Masrur 1998; Vaqāsi Lemar 1998 (rice cultivation); Pur-Mohammadi Amlashi 1999; Rafíi and Mirzājān 2001.

${ }^{23}$ Danielle Guizzo is writing a dissertation in Naples on Talishi. 


\section{Conclusion}

The state of research on the land and people of Talish may best be characterised as uneven. Marcel Basin's thorough studies cover a wide range of subjects, including natural and economic geography, demography, and material culture of the Iranian part of Talish. Nonetheless, studies on subjects such as Talishi tribes, the ethnic history of the Talishis, folklore, and spiritual culture are far from being complete. Having been out of the reach of professional ethnographers for the most part of the 20th century, time when the methodical anthropology established itself as an independent scholarly discipline, the former Soviet part of Talish remains largely unknown to the current scholarship. Moreover, little is known about the modern history of Talish.

Concerning the language, the matter of collecting dialect materials is far more complete for the northern part of Talish, the dialectal variation of which is much less pronounced than that of the south, where the dialects and subdialects of Lisār, Kargānrud, Tulārud, Khushābar, Shānderman, etc. remain largely unexplored. Not only detailed analysis of each dialect, but also a comparative study of the Talishi dialects and their relationships with the neighbouring Tati and Ázari idioms is yet to be conducted. 


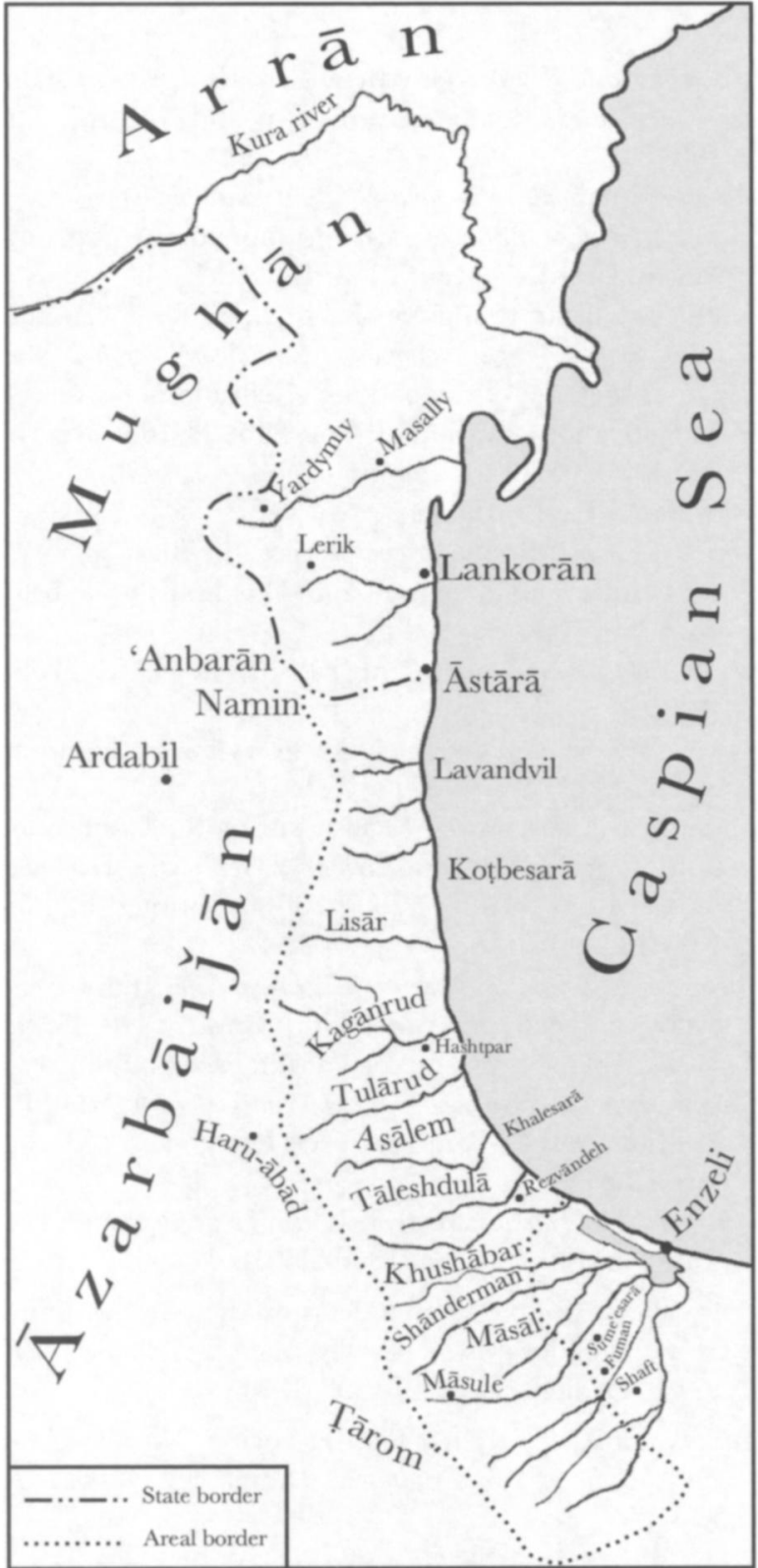

Map of Talish

(Habib Borjian \& Uwe Bläsing) 


\section{BIBLIOGRAPHY}

'Abdoli, 'Ali, Tälešihā kistand? [Who are the Talishis?], Enzeli, 1363/1984a.

_- Farhang-e täti o tāleši [Dictionary of Tāti and Talishi], Enzeli, 1363/ 1984b.

__, (ed.), Tarānehā-ye šomāl: sorudahāa-yi az šă erān-e bināmonešān-e Gilān o Māzandarān [Caspian songs from anonymous poets of Gilan and Mazandaran], Tehran, 1368/1989a.

__ , "Tarānehā-ye šālizār [Songs of the rice paddies]", Rahim Cherāghi, (ed.), Sedā-ye šălizār: majmu'e-ye še'r o maqāl darbāre-ye berenj o berenj$k \bar{a} r i$ [The voice of the paddies: Collection of articles on rice and its cultivation], Rasht, 1368/1989b: 93-104. (Reprinted in 'Abdoli 1990: 63-77).

_-, Tärikh-e Kadüshä, Rasht, 1989c.

_-, Matäleb-i dar zamine-ye tārix, farhang o jāme'e-ye Täthā va Tālešān [On the culture and society of the Tāts and the Talishis], Tehran, $1369 / 1990$.

__ Áftāvajār [The author's poems in Talishi and Tāti], Tehran, 1370/ 1991.

__, Nazar-i be jāme'e-ye 'ašāyeri-e Tāleš [An overview of the nomadic society of Talish], Tehran, 1371/1992.

_- "Tāleš dar 'asr-e mašrutiyyat [Talish during the Contitutional Revolution]", Iraj Afs̄ār, (ed.), Nāmvāre-ye Doktor Mahmud-e Afs̄ār 10, Tehran, 1377/1998: 5708-5738. (Reprinted in 'Abdoli 1999a: 133-191).

_- Čahār resāle dar zamine-ye tārix o joghrāfiā-ye Tāleš [Four treatises on the history and geography of Talish], Rasht, 1378/1999a.

_- Mašāhir-e Tāleš [Famous persons of Talish], Rezvānshahr, 1378/1999b.

_-, (ed.), Adabiyyāt-e Tät o Tāleš-e Irān o Jomhuri-e Āzarbāyejān [Tati and Talishi literature in Persia and the Republic of Azerbaijan], Tehran, 1380/2001a.

_ Farhang-e tatbiqi-e Tāleši-Tāti-Āzari [Comparative dictionary of TalishiTati-Turkish], Tehran, 1380/2001b.

'Ābedi, Kāmiār, "Fehrestnāme-ye motāle'āt o tahqiqāt-e pirāmun-e guyeš-e àzari [Bibliography of studies on Āzari dialect]", Kādeh (viže-ye Täleš), Ordibehešt 1372/1993, Rasht.

Aglarov, Mamaykhan A., "Talysh", Paul Friedrich, Norma Diamond, (eds.), Encyclopedia of World Cultures V. Russia and Eurasia/China, Boston, 1994: 354-357.

Ahmadi, Hoseyn, Tālešān: az dowre-ye Safaviye tā pāyān-e jang-e dovvom-e Irān o Rus [The Talish: from the Safavids to the end of the second RussoPersian war], Tehran, 1380/2001. 
Amiriān, Robābe, Barrasi-e guyeš-e 'Anbarān [Study on the dialect of 'Anbarān], M. A. thesis, supervised by Irān Kalbāsi, Dānešgāh-e Azād-e Eslāmi, Tehran, 1380/2001.

Anserov N. I., Talyši. Mediko-antropologičeskoe issledovanie, Baku, 1932.

Āqājāni Tālesh, 'Abd-al-Karim, Jostārhā-yi dar tārikh-e Tāleš [Essays on the history of Talish], 2 vols., Tehran, 1378/1999.

Asatrian, Garnik, "Dim(i)li: People and Language", EIr., vol. VII/4, 1995: 405-411.

, Etjudy po iranskoj etnologii [Essays on Iranian Ethnology], Erevan, 1998.

, [Review of Osnory iranskogo yazykoznaniya, II, Moscow, 1997], Iran and The Caucasus, vol. 5, 2001: 247.

_- "The Lord of Cattle in Gilan", Iran and the Caucasus, vol. 6/1-2, 2002: 75-85.

—_, "Gorūh-e lahjehā-ye daryā-ye Khazar va Āzarbāyjān” (Manuscript).

- V. A. Livshits, "Le systém consonantique de la langue kurde", Acta Kurdica 1, 1994: 81-108.

Atlas Azerbajdžanskoj SSR, Moscow, 1963.

Āzmude, Shahrām, "Vāžehā-ye tāleši dar berenjkāri [Terminology of rice cultivation in Talishi]", Gilevā 3, 1373/1994: 41-42.

__, "Nāmhā-ye tāleš-e parandegān [Bird names in Talishi]", Gilevā 5, 1375/1996a: 45.

__ , "Vāžegān-e tāleši dar parvareš-e gāv o gusfand [Terminology of animal husbandry in Talishi]", Naqš-e qalam, 1375/1996b: 4.

_-, "Nāmhā-ye tāleši [Talishi names]", Āvā-ye šomāl (Viže-ye tālešihāa), 1377/ 1998: $5 \mathrm{ff}$.

Bailey, H. W., s.v. "Persia, II-Languages and Dialects", Encyclopaedia of Islam, 1st ed., vol. 3, 1936.

—_, “Ambages Indoiranicae”, AION-L 1, 1959: 113- 146.

Barthold (Bartol'd), V. V. (W.), s.v. "Talish", Encyclopaedia of Islam, lst ed.

- Sočineniya, tom VII, Moscow, 1976.

Bazin, Marcel, "Le Tâlech et les tâlechi: Ethnic et region dans le nord-ouest de l'Iran", Bulletin de l'Association de Geographes Français, no. 417418, 1974: 161-170; Pers. tr. by Sirus Shamisā, "Tāleš o sākenān-e ān", Majalle-ye Dāneškae-ye adabiyāt o 'olum-e ensāni-e Dānešgāh-e Ferdowsi 11/3, 1354/1975: 383-401.

_-, "La Penetration turque dans les Tâlech", L'acculturation turque dans l'Orient et la Mediterrané, Colloque international du C.N.R.S., Oct. 1975, Paris.

_-, "Les bazars saisonniers de montagne dans le Taleš", G. Schweizer, (ed.), Beiträge zur Geographie orientalischer Städte und Märkte, Wiesbaden, 1977: 201-11. 
_-, "Le culte des arbres et des montagnes dans le Tâleš (Iran du NordOuest)", Quand le crible était dans la paille... Hommage à P. N. Boratav, Paris, 1978: 95-104

_-, "Recherche des papports entre diversité dialectale et geographie humaine: l'example du Tâleš", G. Schweizer, (ed.), Interdisciplinäre Iran-Forschung: Beiträge aus Kulturgeographie, Ethnologie, Soziologie und Neuerer Geschichte, Wiesbaden, 1979: 1-15.

__, Le Tâlech: une région ethnique au nord de l'Iran, 2 vols., Paris, 1980.

—-, "Quelque échantillons des variations dialectales du tâleši", Studia Iranica 10, 1981: 111-124, 269-277.

_, "Ethnies et groupes socio-professionnels dans le nord de l'Iran", in J.P. Digard, (ed.), Le fait ethnique en Iran et en Afghanistan, Paris 1988: 77-88.

__, "Le Tâleš revisité", Studia Iranica 25/1, 1996: 115-134.

—_, "La région, cette inconnue... Réflexions sur l'identité régionale dans le monde Turco-iranien", Hommes et terres d'islam: Mélanges offerts à $X$. De Planhol, tome II, Téhéran, 2000: 345-359.

__, Bromberger C., Gilān et Āzarbājjān oriental: Cartes et documents ethnographiques, Paris, 1982; Pers. tr. by M. Amin Farshchiān as Gilān o Āzarbāyjān-e šarqi. Naqšsehā va asnād-e mardomšenāsi, Tehran 1365/1987.

Berezin, Il'ya Nikolaevich, Putě̌estvie po severnoj Persii [Travel in northern Persia], Kazan, 1852.

- (E. Berésine), Recherche sur les dialects persans, 3 parts, Casan (Kazan), 1853.

Borjian, Habib, "Tarkib-e qowmi-e Qafqāz [Ethnic composition of the Caucasus]", Irānšenāxt, no. 10, Fall 1998: 206-241.

_-, "Do ketāb darbāre-ye Tāleš o mašāhir-e ān" [Review of 'Abdoli's Čahār resāle (2000) and Mašāhir-e Tāleš (1999)], Našr-e dāneš 19/2, Summer 1381/2002: 46-50.

- , [Review of Schulze 2002], Iran and the Caucasus, vol. 8/2, 2004: 165168.

Browne, Edward, A Literary History of Persia, 4 vols., Cambridge, 1928.

Chodzko, Aleksandr (Alexander) Borejko, Specimens of the Popular Poetry of Persia as found in the Adventures and Improvisations of Kurroglou, the Banditminstrel of Northern Persia; and in the Songs of the People inhabiting the Shores of the Caspian Sea. Orally collected and translated, with philological and historical Notes, London, 1842; 2nd ed., London, 1964.

_-, "Chants populaires des côtes méridionales de la mer Caspienne: dialectes ghilek, taliche et mazendérani", La révue orientale et algérienne 3/4, 1852: 441-465.

Chursin, G. F., "Talyši (Etnografičeskie zametki)", Izvestiya Kavkazkogo istorikoarxeologičeskogo ob̌̌čestva, vol. 4, Tiflis, 1926: 16-45. 
CLI = Compendium Linguarum Iranicarum, ed. Rüdiger Schmitt, Wiesbaden, 1989.

Dabir-siyāqi M. (ed.), Hamd-Allāh Mustaufì Qazvīnī, Nuzhat al-qulūb, Tehran, $1381 / 2003$.

Dorn, Boris Andreevich, "Bericht über eine wissenschaftliche Reise in dem Kaukasus und den südlichen Küstenländern des kaspischen Meeres", Bulletin de l'Academie Imp. de Sciences de St.-Pétersbourg IV, 1862: 344-377.

—, Beiträge zur Kenntnis der iranischen Sprachen, II Teil., St.-Petersburg, 1866.

_-, "Caspia. Über die Einfälle der alten Russen in Tabaristan" [originally in Russian], Mémoire de l'Academie Imp. de Sciences de St.-Pétersbourg, VII ${ }^{\mathrm{e}}$ serie, t. XXXIII, no. 1, St.-Petersburg, 1875.

Dowlatābādi, 'Aziz, "Ašsāâr va molamma'āt-e gilaki-e Qāsem-e Anvār [Gilaki poems of Qāsem Anvār]", Āyande 10/8-9, 1363/1984: 553-56.

D'yakonov, I. M., Istoriya Midii ot drevnejšix vremen do konca IV veka do n.e., Moscow-Leningrad, 1956.

__ , "K metodike issledovanij po etničeskoj istorii ("Kimmerijcy")", Etničeskie problemy istorii Central'noj Azii v drevnosti, Moscow, 1981: 90101.

Eichwald, Eduard, Reise auf dem Kaspischen Meere und in den Kaukasus (1825-1826) I, Stuttgart, 1834.

EIr. = Encyclopaedia Iranica, ed. Ehsan Yarshater, New York, 1982ff.

Fraser, James B., Travels and Adventures in the Persian Provinces on the Southern Banks of the Caspian Sea, London, 1826.

Geiger, Wilhem, "Die kaspischen Dialekte", W. Geiger, E. Kuhn, (eds.), Grundriss der iranischen Philologie, Strassbourg, 1898-1901, vol. I, part 2: 344-380.

Guizzo, D., "Motāle‘āt-e dānešmandān-e šuravi darbāra-ye guyeš-e tāleši [Studies of Soviet scholars on the Talishi dialect]", Hassan Rezai Baghbidi, (ed.), Proceedings of the First Seminar of Iranian Dialectology (2001), Tehran, 2002: 491-497.

Hājatpur, Hamid, Barrasi-e guyeš-e tāleši (dehestān-e Khušābar) [nvestigation of the Talishi dialect of Khushābar], M. A. thesis, guided by 'AliAshraf Sādeqi, Dept. of Language and Literature, Dānešgāh-e Azād-e Eslāmi, Central Tehran Branch, 1369/1990a.

__, "Āzari yā tāleši”, Majalle-ye zabānšenāsi 7/2, 1369/1990b: 59-62.

—_, "Guyeš-e tāleši [of Tāleshdulāb]", Majalle-ye zabānšenāsi 12/1-2, 1374/ 1995 (published in 1376/1997): 96-112.

—_ Zabān-e tāleši (guyeš-e Xušăbar), Dushanbe, 1382/2003; repr. Rasht, $1383 / 2004$.

Hāmedi, Nāser, Čan-ba-rā [Talishi poems], Tehran, 1378/1999. 
Henning, W. B., "The Ancient Language of Azerbaijan", Transactions of the Philological Society, London, 1954: 157-177.

Ḥesām al-Salțaneh, Ab-ol-Nașr Mirzā, Safar-nāme-ye Tavāleš, Tehran, 1968.

Hübschmann H., Armenische Grammatik, 1. Teil, Leipzig, 1897.

Izmajlova, A. K., "Iz istorii razvitiya žilišča yugo-vostočnyx rajonov Azerbajdžana [From the history of the development of the dwelling places in the south-eastern regions of Azerbaijan]", Azerbaydžanskij etnografičeskij sbormik, Baku, 1977.

Ketāb-e Gilān [Book of Gilān], ed. Ebrāhim Eslāh-'Arabāni, 3 vols., Tehran, 1374/1995.

Ketäbšenāsi-e Gilān [Bibliography of Gilān], ed. Mohammad-Taqi Pur-Ahmad Jaktāji, Fereshte Tālesh-Ensāndust, and Sayyed-Hasan Ma'sumi-Eshkavari, 2 vols., Rasht, Sāzmān-e barnāme va budje, 1368-70/1989-91.

Khādemi Arde, Ebrāhim, Farhang-e albasa-ye Tāleš [Glossary of Talishi clothing], M. A. thesis, supervised by Esmā'il Hākemi, Dānešgāh-e Azād-e Eslāmi, Tehran, 1376/1997.

Kirakosyan, Hasmik, "Soxani darbāre-ye zabān-e kohan-e Azarbāyjan", Back to Erānšahr: Festschrift for Garmik Asatrian, Yerevan, 2003: 35-39.

-, "The Common Characteristics of the Textual Attestations of Azari", Society, History and Culture in the Persianate World (Abstracts), Yerevan, 2004a: 73.

- Azarin, Atrpatakani hin lezun [Azari, the ancient language of Aturpatakan] (PhD dissertation), Dept. of Iranian Studies, Yerevan State University, 2004b.

Lazard, Gilbert, "Le dialecte tāleši de Māsule (Gilān)", Studia Iranica 7/2, 1978: 251-268.

__, "Textes en tāleši de Māsule", Studia Iranica 8/1, 1979a: 36-66.

__, "Glossaire māsulei”, Studia Iranica 8/2, 1979b: 269-275.

Lecoq, P., "Les dialectes caspiens et les dialectes du nord-ouest de l'Iran", CLI: 296-312.

Madani, Rezā, "Pir-e Sharafs̄āh o negāh-i be Divān-e bāzyāfte-aš", Rezā Rezāzāde Langarudi, (ed.), Yādegār-nāme-ye faxrāi, Tehran, 1363: 757-779.

__, "Ketābšenāsi o barrasi-e vāženāmehā, dasturnāmehā va neveštehā-ye gilaki o deylami o tāleši, az sade-ye haštom tā konun [Bibliography and study of glossaries, grammars and writings in Gilaki, Deylami and Talishi since 14th century]", Gilān-nāmeh II, Rasht, 1369/1990: 336-395.

Mamedov, N., Šuvinskij govor talyšskogo yazyka [Talishi dialect of Shuvi], (PhD dissertation), Baku, 1971.

__, Toleši armağon [Souvenir from Talish], Baku, 1993. 
Mann, Oscar, Kurdisch-persische Forschungen, pt. 3, vol. 1, Berlin, 1926.

Marquart, J., Osteuropäische und ostasiatische Streifzüge, Leipzig, 1903.

Marr, N., Talyši, Petrograd, 1922.

Masrur, Farāmarz, Manzume-ye Khandila Pešt, tāleši [The Talishi versified story of Kandila Pesht], s. 1. (Rasht?), 1352/1973.

_-, "Gostardegi-e vāžegān-e tāleši", Āvā-ye šomāl (Viže-ye tālešihāa), 1376/ 1997: 6f., 1377/1998: 9.

Miller, Boris Vsevolodovič, "Predvaritel'nyj otčet o poezdke v Talyš letom $1925 \mathrm{~g}$. [Preliminary report on a journey to Talish in the summer of 1925]", Izvestiya obščstva obsledovaniya i izučesniya Azerbajdžana, Baku, 1926, no. 1: 24-36.

—, K voprosu o yazyke naseleniya Azerbajdžana do oturě́eniya etoj oblasti, Moscow, 1930.

—, Talyšskie teksty [Talishi texts], Moscow, 1930.

—, Talyšskij yazyk [The Talishi Language], Moscow, 1953.

Mirzā Ahmad Lankorāni's Axbār-nāmeh [Book of information], ed. 'Ali 'Abdoli, Tehran, 1380/2002.

Mirzā Ebrāhim, Safarnāme-ye Astarābād o Māzandarān o Gilānn... , ed. by Mas'ud Golzāri, Tehrān, Bonyād-e Farhang-e Irān, ser. no. 238, 2535/ 1977.

Mohammadizadeh Khoshru, Yussef, A Description of Taleshi Dialect of Masuleh, M. A. thesis, guided by S. Rahbarnia, Dept. of Linguistics, University of Shiraz, 1996.

Morgan, Jacques de, Mission scientifique en Perse, 5 vols., Paris, 1894-1904.

Morgenstierne, Georg "Neu-iranische Sprachen", Bertold Spuler (ed.), Handbuch der Orientalistik 1/4, i. Iranistik: Linguistik, Leiden, 1958: 157178.

Naghzgu-Kohan, Mehrdād, Barrasi-e guyeš-e Täleš (dehestān-e Tāskuh-e Māsāl)

[Study on the Talishi dialect of Tāskuh, a village district of Māsāl], M. A. thesis, guided by 'Ali-Mohammad Haqshenās, Dept. of General Lingustics, University of Tehran, 1374/1995.

__ , "Towsif-e sāxtemān-e fe_l dar guyeš-e tāleši-e dehestān-e Tāskuh-e Māsāl [Description of verb structure in the Talishi dialect of Tāskuh]", Majalle-ye zabānšenāsi 11/1, 1373 (published 1375/ 1996): 38-57.

Nawata, Tatsuo, "The Masal Dialect of Talishi", Acta Iranica 22, Leiden, 1982: 93-117.

Oranskij, Iosif M., Vvedenie v iranskuyu filologivu, Moscow, 1960.

__ Iranskie yazyki, Moscow, 1963; tr. Les langues iraniennes, by Joyce Blau, Paris, 1977; and Zabānhāa-ye Irāni, by 'Ali-Ashraf Sādeqi, Tehran, 1378/1999. 
, Die neuiranischen Sprachen der Socejetunion, translated by Werner Winter from the 1969 Russian edition, The Haugue, 1975.

Pirejko, L. A., Sravnitel'naya xarakteristika prošedšix vremen perexodnyx glagolov v kurdskom i talyšskom yazykax, Dissertaciya, 1956, Moscow.

__, "Ergativnaya konstrukciya v kurdskom i talyšskom yazykax", Kratkie soobščeniya Instituta narodov Azii SSSR 30, 1961: 86-94.

—_, "Talyšskij yazyk [Talishi language]", Mazyki narodov SSSR, Moscow, 1966: 302-322.

, Talyšsko-russkij slovar' [Talishi-Russian Dictionary], Moscow, 1976.

—, "Talyšskij yazyk. Dialekty tati Irana", Osnovy Iranskogo yazykoznaniya, tom V. Novoiranskie yazyki, Moscow, 1991: 91-175.

Pur-Mohammadi Amlashi, N., "Āvā-ye vāžegān”, Āvā-ye šomāl (Viže-ye tālešihā), 1378/1999: 16ff.

Qāsem Anvār, Kolliyāt, ed. S. Nafisi, 2nd ed., Tehran, 1337/1958.

Rabino, H. L., Les provinces caspiennes de la Perse. Le Guîlān, Paris, 1917; pers. Transl. by Ja'far Khomāmizāde as Velāyāt-e Dār al-marz-e Gilān, Tehran, 1350/1971.

_-, "Čegunegi-e gozaštan-e owqāt-e farāghat-am dar Irān”, Ruzegār-e now [London-New York] 3/4, 1943-44: 48-58.

Radde, Gustav, "Talysch, das Nordwestende des Alburs und sein Tiefland. Eine physiko-geografische Skizze", Petermanns Mitteilungen aus Fustus Perthes' Geographischer Anstalt 31, 1885: 254-267, cited by Geiger: 345

_- Reisen an der persisch-russischen Grenze. Talysch und seine Bewohner, Leipzig, 1886.

Rafi'i-'Ali, Ma'sume Mirzājān, "Vākehā-ye zabān-e tāleši”, Naq̌̌-e qalam (vižéye tāleš-šenäsi), no. 3, 1380/2001: 3-8.

Rajabov, Abulfazl, Šogirdi tolyši-tyrki ljugat [Talishi-Turkish apprentice dictionnary for students], Baku, 1992.

Redard, Georges, "Other Iranian Languages", Thomas A. Sebeok (ed.), Current Trends in Linguistics IV. Linguistics in South West Asia and North Africa, The Hague, 1970: 97-135.

Reichelt H., "Iranisch", Die Erforschung der indogermanischen Sprachen, Bd. 4, 2. Hälfte, Berlin-Leipzig, 1927: 1-84.

Rezāyati-e Kišekhāle, Moharram (or Mahram), Torwsif-e guyeš-e tāleši [Description of the Talishi [of Parasar]], M. A. thesis, Mashhad University, s.a.

—_, [Review of 'Abdoli 2001b], Guyeš-šenāsi 1/1, 2002: 127-134.

"Čand nokte-ye dasturi dar guyeš-e tāleši [Grammar notes on the Talishi of Shafārud in Punel and of Nāvrud in Asālem]", Guyeš-šenāsi 1/1, 2003: 41-52. 
Riss, P. F., "O talyšintcax, ix obraze žizni i yazyke [TheTalishis, their life and language]", Zapiski Kavkazskogo Otdelenia imperatorskogo russkogo geografičeskogo obščstva, vol. 3, Tiflis, 1855: 1-72.

Sādeqi, 'Ali-Ashraf, [Review of 'Abdoli 1984], Majalle-ye zabānšenāsi 1/2, 1984: 109-111; reprinted in idem, Negāh-i be guyešnāmehā-ye irāni, Tehran, 1379/2000.

Sbomik materyalov dlya opisaniya mestnostej i plemen Kavkaza [Collection of materials on the localities and tribes of the Caucasus] 20/2, Tiflis, 1894: 17-24.

Schmidt M. G., Die Nebenüberlieferungen des 6. Buchs der Geographie des Ptolemaios. Griechische, lateinische, syrische, armenische und arabische Texte, Wiesbaden, 1999.

Schmitt, Rüdiger, "Cadusii”, EIr., s.v.

Schulze, Wolfgang, Northern Talysh, Munich, 2000.

Sharafshāh Dulā’i, Divān, ed. M.-'A. Sowti, BFI, Tehran, 1358/1979.

—- Divān-e kučak, ed. A. Savār-e Rakhsh, Tehran, 1361/1982.

Sheikh Sang Tajan, Shahin, Barrasi-e 'anāser-e vājšenāxti-e guyeš-e tāleši [Study on Talishi phonology], M. A. thesis, guided by Mahmud Bi-jankhān (sic!), University of Tehran, 1380/2001.

Simonyan, H., Patmut'izen Aleksandri Makendonac 'woy, Erevan, 1989.

Sokolova, V. S., Očerki po fonetike iranskix yazykov. I beludžskïj, kurdskij, talyšskij, tatskij yazyki [Studies on the phonetics of Iranian languages. I. Baluchi, Kurdish, Talishi, Tati[-Persian] Languages], Moscow, 1953.

_-, Issledovaniya po fonetike iranskix yazykov, Doctoral dissertation, Leningrad, 1954.

Sotudeh, Manuchehr, Az Astārā tā Estāāābād I/ 1: Așār o banāhā-ye tārixi-e Gilān-e Bie-pas, Tehran, Anjoman-e Așār-e Melli, 1349/1970.

Spisok narodnostei S.S.S.R., pod redakciej I. I. Zarubina, Leningrad, 1927.

Stilo, Donald L., "The Tati Language Group in the Socio-linguistic Context of North-west Iran and Transcaucasia", Iranian Studies 14/3-4, 1981: 137-187.

Tabarī, Annales quos scripsit Abu Djafar Mohammed ibn Djarir at-Tabari, cum aliis ed. M. de Goege, Lugduni Batavorum, series I, t. I-VI, 18791890.

Tadayyon, 'Atā'-Allāh, "Qāsem-e Anvār o ghazal-i ke be zabān-e gilaki sorud", Amaghān 26/4, 1324/1945: 342-344.

Ter-Abrahamian, Hrant, "On the Formation of the National Identity of the Talishis in Azerbaijan Republic", Iran and the Caucasus, vol. 9.1, 2005: 121-144. 
Vaqāsi Lemar, Teymur, "Vāžehā-ye tāleši dar šālikāri", Āvā-ye šmāll (viže-ye tālešihā), 1377/1998: 9.

Vil'čevskij, O. L., "Gilyaki, galeši, talyši”, N. A. Kislyakova, ed., Narody perednej Azii, Moscow, 1957: 225-241.

Weidenbaum, E., Putevoditel' po Kavkazu, Tiflis, 1888.

Windfuhr, Gernot, "Convergence. Iranian Talishi and Turkic Azari", Selected Papers from SALA-7. South Asian Roundtable Conference, Bloomington, Ind., 1987: 385-405.

Yarshater, Ehsan, "Tālish”, Encyclopaedia of Islam, 2nd ed., vol. 10.

—, "The Iranian Language of Azerbaijan", Encyclopaedia Iranica, s.v. "Azerbaijan, vii".

-, "The dialect of Shāhrud (Khalkhāl)", Bulletin of the School of Oriental and African Studies, 22/1, 1959: 52-68.

—, "The Tāti Dialect of Kajal", Bulletin of the School of Oriental and African Studies, 23/2, 1960: 275-286.

—- A Grammar of Southern Tati Dialects, The Hague, 1969.

—_, "The Tāleshi of Asālem", Studia Iranica 25/1, 1996: 83-113.

Ziegler, Susanne (with H. Humbach), Ptolemy Geography, Book 6 (Middle East, Central and North Asia, China), part 1, Wiesbaden, 1998. 